\title{
Characterization and Evaluation of Human Health Risk of Heavy Metals in Tin Mine Tailings in Selected Area of Plateau State, Nigeria
}

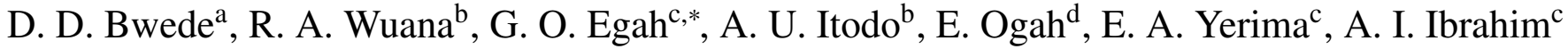 \\ ${ }^{a}$ Department of Basic Sciences, Plateau State College of Health Technology Zawan, Nigeria \\ ${ }^{b}$ Department of Chemistry Federal University of Agriculture Makurdi, Benue State, Nigeria \\ ${ }^{c}$ Department of Chemical Sciences, Federal University Wukari, Taraba State, Nigeria \\ ${ }^{d}$ Department of Chemistry University of Jos, Jos, Plateau State, Nigeria
}

\begin{abstract}
Tin mining tailings are unprocessed waste materials that overlie an ore which are displaced during mining activities. This research work is aimed at characterizing and evaluating the human health risk of heavy metals in tin mine tailings in Zabot (S3) and Tafan (S4) districts in Barkin Ladi Local Government Area of Plateau State, Nigeria. The samples were characterized using EDX-XRF and SEM. The concentrations of seven heavy metals ( $\mathrm{Pb}, \mathrm{Cr}, \mathrm{As}, \mathrm{Ni}, \mathrm{Cd}, \mathrm{Cu}$ and $\mathrm{Zn}$ ) were determined in S3 and S4. The results showed that $\mathrm{Cr}, \mathrm{Ni}, \mathrm{Cd}, \mathrm{Cu}$ and $\mathrm{Zn}$ were within the USEPA permissible limits, except for $\mathrm{Pb}$ and $\mathrm{As}$ with range of (270-300) $\mathrm{mg} / \mathrm{kg}$ and (40-70) $\mathrm{mg} / \mathrm{kg}$ respectively for both mining and control sites of $\mathrm{S} 3$ and S4. The SEM results revealed small particles size with fine porous structure, and rough areas with varying sizes and pores distributed over the surface for S3 and S4 respectively. Results of the risk assessment showed that the hazard quotient HQ and HI values were greater than 1 indicating high risk. The Carcinogenic and non-carcinogenic risks associated with $\mathrm{Pb}, \mathrm{Zn}, \mathrm{Cd}, \mathrm{Cr}$, Ni and As were evaluated for S3 and S4 for the three exposure pathway and it was found that the mining sites pose more risk than the control and the children were more exposed than the adults. The carcinogenicity of these samples were due to the high hazard quotient for ingestion and dermal exposure pathway. The $R_{\text {total }}$ results for As, $\mathrm{Cr}, \mathrm{Pb}$ and $\mathrm{Ni}$ for mining site $\mathrm{S} 3$ were found to be $\left(1.39 \times 10^{2}, 2.02 \times 10^{-7}, 3.30 \times 10^{3}\right.$ and $\left.8.17 \times 10^{-8}\right)$, and control site $\left(3.42 \times 10^{3}, 2.64 \times 10^{-5}\right.$, $38.30 \times 10^{1}, 6.90 \times 10^{-8}$ ) for $\mathrm{As}, \mathrm{Cr}, \mathrm{Pb}$ and $\mathrm{Ni}$ respectively. From the $R_{\text {total }}$ results As and $\mathrm{Pb}$ were more than the acceptable threshold, while $\mathrm{Cr}$ and $\mathrm{Ni}$ were below the threshold of $1 \times 10^{-4}$. For the mining site S4, the $R_{\text {total }}$ were found to be $\left(5.70 \times 10^{2}, 1.82 \times 10^{-7}, 3.63 \times 10^{4}\right.$ and $\left.9.64 \times 10^{-9}\right)$, and the control $\left(1.16 \times 10^{3}, 1.71 \times 10^{-7}, 31.1 \times 10^{2}\right.$ and $\left.1.51 \times 10^{-8}\right)$ for $\mathrm{As}, \mathrm{Cr}, \mathrm{Pb}$ and $\mathrm{Ni}$ respectively. From the results of the mining and control sites, As and $\mathrm{Pb} R_{\text {total }}$ were higher than the acceptable threshold, while $\mathrm{Cr}$ and Ni were below the threshold of $1 \times 10^{-4}$.
\end{abstract}

DOI:10.46481/jnsps.2021.262

Keywords: Tailings, Heavy metals, Hazard Index, Carcinogenic Risk and Hazard Quotient

Article History :

Received: 18 June 2021

Received in revised form: 16 September 2021

Accepted for publication: 17 September 2021

Published: 29 November 2021

(C)2021 Journal of the Nigerian Society of Physical Sciences. All rights reserved. Communicated by: S. J. Adebiyi

${ }^{*}$ Corresponding author tel. no: +2347061097995

Email address: egah.godwin@yahoo.com (G. O. Egah)

\section{Introduction}

Tin mining tailings are wastes fractions of an ore or mineral body which are discarded during mining operations without being processed. Tin tailings contains both magnetic minerals 
(iron ore, columbite) and non-magnetic minerals (cassiterite, monozite, zircon sand in large quantity and silica) [1]. They are used in preparation of fertilizer, animal feeds, refractory products, for building roads and backfilling of tailing storage facilities [2].

In the 1960s, Nigeria was regarded as one of the world's leading tin producing country, but production later decreased towards the end of the twentieth century. However, mining activities are still going on in these areas. Apart from tin which is the primary target, tin mining generates tin tailings, which are by-product of the ore. The amount of tailings produced ranged from $90-98 \%$ for copper ores and $20-50 \%$ for other minerals [3]. Some of the heavy metals found in contaminated tailings are $\mathrm{Pb}, \mathrm{Cr}, \mathrm{As}, \mathrm{Zn}, \mathrm{Cd}, \mathrm{Cu}, \mathrm{Ni}$ and $\mathrm{Hg}[4,5,6]$. Heavy metal contamination and their human health threats are some of the serious environmental problems limiting mining activities $[7,8]$.

With the development of mining, smelting and other industrial activities, heavy metals are increasingly being found in the environment which can pose severe threats to humans and the environment. Pollution by heavy metals such as lead $(\mathrm{Pb})$, chromium (Cr), arsenic (As), nickel (Ni), cadmium (Cd), copper $(\mathrm{Cu})$ and zinc $(\mathrm{Zn})$, affects the quality of the ambient air, soil and water bodies which in turn threatens the life of both animals and humans through the food chain [2].

During mining activities huge waste tailing ponds are created which have a high environmental impact on the surrounding ecosystems and populations when used $[9,10]$. In order to evaluate the risk posed by tin mine tailings activities to human health, there is need to assess the level of heavy metal pollution in these sites and the rate at which they affects human life. This is based on preliminary studies on waste properties, heavy metals concentration and their relation to the environment as they affect the individuals who participated in these tailings activities and the community [11].

Human health risk assessment involves the evaluation of possible human health effect in the contaminated environmental media [12]. The health effect of contaminants on humans depends on the level of exposure, nature of the contaminants and vulnerability of the individual affected [13]. Health effects may include risk of cancer, hypertension, acute foetus neurological disorders, organ dysfunction, respiratory difficulties, physical and mental disorder, reduced life expectancy and weakening of the body's immune system [12].

Therefore, this research is aimed at characterizing and evaluating the human health risk of heavy metals in tin mine tailings in Zabot and Tafan district both represented by S3 and S4 respectively in Barkin Ladi Local Government Area, Plateau State, Nigeria.

\section{RESEARCH METHODOLOGY}

\subsection{Sample Location and Description}

This research work was carried out in Zabot (S3) and Tafan (S4) district of Barkin Ladi Local Government Area of Plateau State, Nigeria. It is located between latitude $9051^{\prime} 30^{\prime \prime} \mathrm{N}$ and longitude $8048^{\prime} 00^{\prime \prime} \mathrm{E}$. The state is located in the middle belt of Nigeria, with an area of $30.91 \mathrm{~km}$ (11936 square mile). The state has a population of about three million people in estimate. The name Plateau State was given because of its topography with wonderful rock formations. The height of the mountains ranges from 1,200 to 1,829 meters above sea level. Mining and subsistence farming are the major occupation of its residents. The sampling locations and points are as shown in Figure 1, using the geographical positioning system (GPS) to locate Zabot (S3) and Tafan (S4).

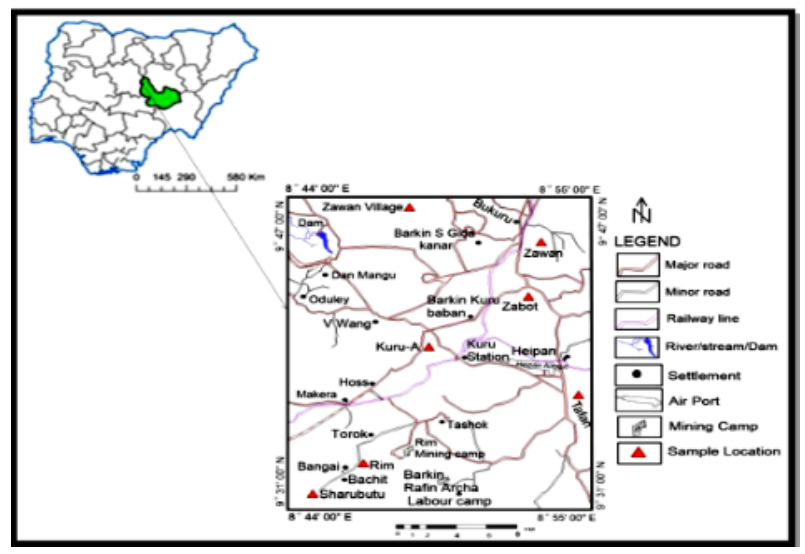

Figure 1. GPS Map Showing the Sites of Sample Collection.

\subsection{Sampling collection and preparation}

The random sampling technique was applied for sample collection with little modification. Two samples of $50 \mathrm{~g}$ each were taken from mining sites in Zabot (S3) and Tafan (S4) in Barkin Ladi Local Government Area of Plateau State, with their respective control. The tin mine tailings and soil samples were washed, dried and pulverized into the required particle sizes of $2 \mathrm{~mm}$. Pre-treatments which does not alter the chemical composition of the analytes were done to obtain the original concentration of the analyte found in the sample.

\subsection{Determination soil $p H$ and Temperature}

$1.0 \mathrm{~g}$ of soil sample from both mining and control sites were mixed with $100 \mathrm{~cm} 3$ of deionized water in $250 \mathrm{~cm}^{3}$ conical flask and stirred using a magnetic stirrer for 10 minutes. The temperature and $\mathrm{pH}$ were determined using Hanna portable $\mathrm{pH}$ meter (model HI8043) and thermometer respectively. The readings were taken in triplicates and the average recorded accordingly. 


\subsection{Sample Characterization}

\subsubsection{Elemental analysis}

The concentrations of the various heavy metals contained in the samples were determined using Energy dispersive X-ray fluorescence spectrometer EDX-XRF (MiniPAL4). The XRF analysis was done directly on solid powdered specimen for accurate results with no risk of contamination. Sample preparation involves milling of the sample to less than $75 \mu \mathrm{m}$ in fraction. Retsch RS 200 vibratory disk milling machine was used at $1500 \mathrm{~min}^{-1}$ motor speed for 5 minutes. The milled sample was collected in XRF cup and placed in the XRF spectrometer and analyzed for chemical composition.

\subsubsection{Determination of Surface Morphology}

The surface morphology of the tailings was determined using scanning electron microscope (SEM-MVE016477830). The sputter coater was operated in an argon atmosphere using a current of $6 \mathrm{~mA}$ for 3 minutes.

\subsection{Human Health Risk Assessment Parameters}

The carcinogenic and non-carcinogenic risks were evaluated using the human health risk assessment model for dermal contact, ingestion and inhalation exposure pathways [13]. The health risk assessment is centered on the exposure factors and guidelines handbook of United States Environmental Protection Agency (USEPA) [14]. The average daily dose (ADD) via inhalation $\left(\mathrm{ADD}_{\text {inh }}\right)$, ingestion $\left(\mathrm{ADD}_{\text {ing }}\right)$ and dermal contact $\left(\mathrm{ADD}_{\text {derm }}\right)$ for both children and adults were evaluated using equations (1) - (3) as adopted from Qing et al., [13].

$$
\begin{aligned}
& \text { Ingestion dose } D_{\text {ing-s }}=\frac{C_{S} \times \operatorname{IngR} \times E F \times E D \times C F}{B W \times A T} \\
& \text { Inhalation dose }\left(D_{\text {inh-s }}\right)=\frac{C_{S} \times I n h R \times E F \times E D}{B W \times A T \times P E F} \\
& \text { Dermal dose }\left(D_{\text {der-s }}\right)=\frac{C_{S} \times S A \times S L \times E F \times E D \times C F}{B W \times A T}
\end{aligned}
$$

where $C_{S}$ is the concentration of the analyte in the tailing from the exposure point $(\mathrm{mg} / \mathrm{kg})$, IngR - tailing ingestion rate for the receptor $(\mathrm{mg} / \mathrm{d}), \mathrm{InhR}$ - soil inhalation rate for the receptor (m3/d), EF - exposure frequency (days/year), ED - exposure duration (years), PEF - soil-to-air particulate emission factor $\left(\mathrm{m}^{3} / \mathrm{kg}\right)$, SA - skin surface area available for exposure $\left(\mathrm{cm}^{2}\right)$, $\mathrm{SL}$ - soil-to-skin adherence factor $\left(\mathrm{mg} / \mathrm{cm}^{2} /\right.$ event), BW - timeaveraged body weight $(\mathrm{kg})$, AT - average time of non-carcinogenic and carcinogenic risks (days) and ABS - dermal absorption factor (dimensionless). The hazard quotient, hazard index and total cancer risk were evaluated using equations (4) - (6) as adopted from Man et al., [15].

The Hazard Quotient is given as:

$$
H Q=\frac{D}{R f D},
$$

where $D=$ Dose (ingestion, inhalation or dermal), RfD = Reference dose. The Hazard index $\mathrm{HI}$ is given as:

$$
H I=H Q_{\text {ing }}+H Q_{i n h}+H Q_{\text {derns }}
$$

Total cancer risk (RT) is given as:

$$
R T=D \times S F,
$$

where $\mathrm{D}=$ Dose, $\mathrm{SF}=$ Slope factor.

Risk characterization was considered separately for carcinogenic and non-carcinogenic effects [16, 17]. Health risks were obtained by comparing the calculated HQ, $\mathrm{HI}$ and $R_{\text {total }}$ values with recommended maximum values shown on Table 1 .

\section{RESULTS AND DISCUSSION}

\subsection{Determination soil $\mathrm{pH}$ and Temperature}

The results of the $\mathrm{pH}$ and Temperature obtained from the study area are presented in Table 2.

The $\mathrm{pH}$ and temperature results of the samples are presented in Table 2. The $\mathrm{pH}$ obtained from the mining and the control sites were $(5.23,5.11)$ and $(7.48,7.21)$ for Zabot and Tafan respectively. The $\mathrm{pH}$ results showed that the two mining sites were slightly acidic, while the control sites were slightly alkaline. The soil temperatures were within the range of 29 to $30^{\circ} \mathrm{C}$, which are suitable for plants growth [19].

\section{Scanning Electron Microscopy of Tin Mines Tailings}

The results of scanning electron microscopy (SEM) for tin mine tailing site S3 and S4 are as shown in Plates 1 (Figure 2) and 2 (Figure 3), respectively.

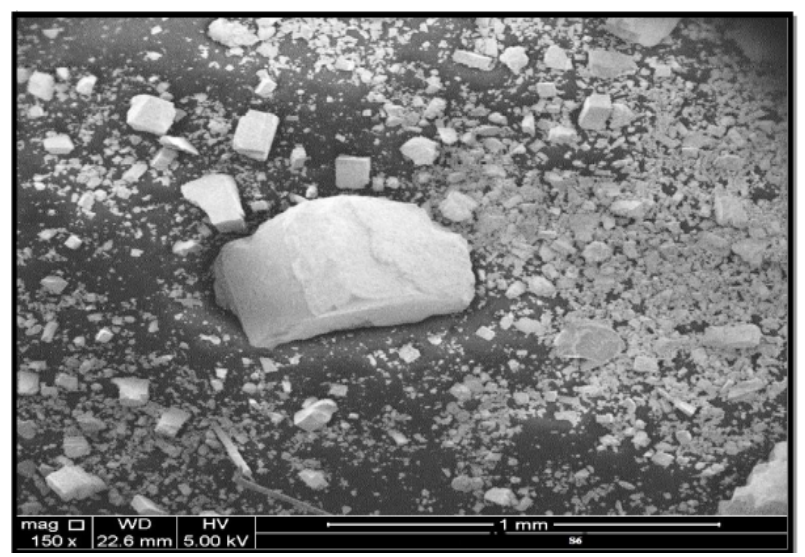

Figure 2. Plate 1: The Scanning Electron Microscope Micrograph (SEM) of Zabot S3.

Result of S3 on Plate 1, showed homogenous small size particles with fine porous structure. While results on plate 2 (S4), showed a micrograph with rough area having different irregular shapes of varying sizes and pores distributed over the surface. The more the number of pores the better the soil aeration [20, 21]. From the two results (Plates 1 and 2), it can be seen that the S4 has more pores than the S3. 
Table 1. USEPA Reference Doses for Non carcinogens and Slope Factor for Carcinogens Source: [18]

\begin{tabular}{ccccccc}
\hline \hline & Rf D $\mathrm{D}_{\text {ing }}$ & $\mathrm{Rf} \mathrm{D} /{\mathrm{mg} . \mathrm{kg}^{-1} . d^{-1}} \mathrm{Rf} \mathrm{D}_{\text {dermal }}$ & $\mathrm{SFing}$ & $\mathrm{SF} /{\mathrm{kg} . \mathrm{d}, \mathrm{mg}^{-1} \mathrm{SF}_{\text {inh }}}$ & $\mathrm{SF}_{\text {dermal }}$ \\
\hline \hline $\mathrm{As}$ & $3.00 \mathrm{E}-04$ & & $1.23 \mathrm{E}-04$ & $1.50 \mathrm{E}+00$ & $1.51 \mathrm{E}+00$ & $3.66 \mathrm{E}+00$ \\
$\mathrm{Cr}$ & $3.00 \mathrm{E}-03$ & $2.86 \mathrm{E}-05$ & $6.00 \mathrm{E}-05$ & & $4.2 \mathrm{E}+01$ & \\
$\mathrm{Cu}$ & $4.00 \mathrm{E}-02$ & $4.02 \mathrm{E}-02$ & $1.20 \mathrm{E}-02$ & & & \\
$\mathrm{~Pb}$ & $1.40 \mathrm{E}-03$ & $3.52 \mathrm{E}-03$ & $5.25 \mathrm{E}-05$ & $8.50 \mathrm{E}-03$ & & \\
$\mathrm{Ni}$ & $2.00 \mathrm{E}-02$ & $2.06 \mathrm{E}-02$ & $5.40 \mathrm{E}-03$ & & $8.40 \mathrm{E}-1$ & \\
$\mathrm{Zn}$ & $3.00 \mathrm{E}-01$ & $3.00 \mathrm{E}-01$ & $6.00 \mathrm{E}-02$ & & & \\
$\mathrm{Hg}$ & $3.00 \mathrm{E}-04$ & $8.57 \mathrm{E}-05$ & $3.00 \mathrm{E}-05$ & & & \\
$\mathrm{RfD}=$ Reference dose and SF=Slope factor & & & \\
\hline \hline
\end{tabular}

Table 2. $\mathrm{pH}$ and Temperature of Tin mine Tailings and Control Soil

\begin{tabular}{ccc}
\hline \hline Sample & $\mathrm{pH}$ & Temperature ${ }^{\circ} \mathrm{C}$ \\
\hline \hline Tin Mine Site S3 & 5.23 & 30 \\
Control S3 & 7.48 & 29 \\
Tin Mine Site S4 & 5.11 & 29 \\
Control S4 & 7.21 & 30 \\
\hline \hline
\end{tabular}

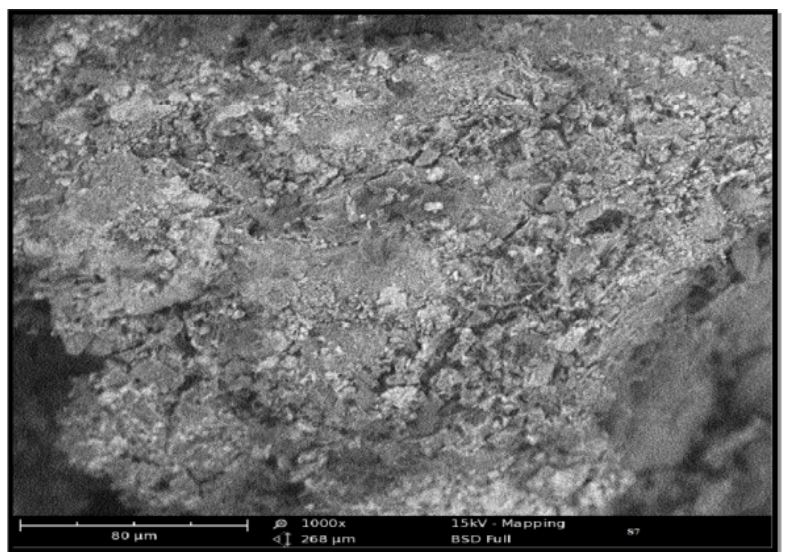

Figure 3. Plate 2: The Scanning Electron Microscope Micrograph (SEM) of Tafan (S4).

\subsection{Heavy Metal Concentration in Tin Mine Tailings and Con- trol Sites}

The heavy metals concentrations of $\mathrm{Pb}, \mathrm{Cr}, \mathrm{As}, \mathrm{Zn}, \mathrm{Cd}, \mathrm{Ni}$ and $\mathrm{Cu}$ in Tin mine tailings and control sites are presented in Table 3.

The results on Table 3, belong to the heavy metals concentrations of the tin mine tailings and the control site in Zabot of Barkin Ladi Local Government Area. These were determined using Energy dispersive X-ray fluorescence spectrometer EDXXRF (MiniPAL4). The results showed that the heavy metals concentrations were within the USEPA permissible limits of the soil, except for $\mathrm{Pb}$ and As with range of (270-300) $\mathrm{mg} / \mathrm{kg}$ and (40-70) $\mathrm{mg} / \mathrm{kg}$ respectively, which are higher than the USEPA permissible limits of 80 and $0.07 \mathrm{mg} / \mathrm{kg}$ for both $\mathrm{Pb}$ and As respectively [22]. The high concentration of $\mathrm{As}$ and $\mathrm{Pb}$ may be traceable to the tin mining activities, farming activities such as application of agricultural chemicals and atmospheric deposi- tions by transport mechanism on the site [19]. This agrees with the work reported by Bwede et al., [3]. The extreme concentration of $\mathrm{As}$ and $\mathrm{Pb}$ may be via bioaccumulation in plant which then enters the food chain when these plants are consumed [22]. Also, the concentrations of the heavy metals from the mining sites are significantly higher than the control sites which may be due to anthropogenic activities within the environment [23]. $\mathrm{Zn}$ found in the area may be as a result of its natural abundance in the parent material [24]. This agrees with the work reported by Banerjee [25], that iron oxides adsorb some quantities of $\mathrm{Zn}$ in the lattice structure.

\subsection{Human Health Risk Assessment of the Site}

The human health risk assessment results for the non-carcinogenic and carcinogenic are shown in Tables 4 - 7 for children and adult respectively. For the non-carcinogenic risk (Tables 4 and 5), if the hazard quotient (HQ) and hazard index (HI) are greater than 1 , then adverse health effects may occur $[15,16]$. Also for carcinogenic risk level (Table 6-7), total cancer risk $\left(\mathrm{R}_{\text {total }}\right)$ values greater $1 \times 10^{-4}$ represents elevated risks, $\mathrm{R}_{\text {total }}$ less than $1 \times 10^{-6}$ does not pose any significant health risk, and $R_{\text {total }}$ values between $1 \times 10^{-4}$ and $1 \times 10^{-3}$ are generally considered acceptable $[26,17]$.

\subsubsection{Non-carcinogenic risk assessment (NCR) for S3 and S4}

The results on Tables $4-5$, are the non-carcinogenic risk assessment of $(\mathrm{Pb}, \mathrm{Zn}, \mathrm{Cd}, \mathrm{Cr}, \mathrm{Ni}$ and $\mathrm{As})$ for $\mathrm{S} 3$ and $\mathrm{S} 4$. The three human exposure routes considered in this study were ingestion, inhalation and dermal exposure. For mining site S3, values of $\mathrm{HQ}$ for ingestion and dermal for children are all greater than 1, except for inhalation which are all less than 1. According to Huang et al., [16], HQ and HI greater than 1 are indication of high cancer exposure risk, while values less than 1 indicates that there are no significant effects. Therefore, since the ingestion and dermal values are greater than 1 , they have high risk exposure. Similar results were observed for adults, except for $\mathrm{Cr}\left(1.69 \times 10^{-1}\right)$ which is less than 1 for ingestion.

For the control (S3), the results of children for the three exposure pathways are greater than 1 , except for $\mathrm{Cr}, \mathrm{Pb}$ and $\mathrm{Ni}$ with values $\left(7.05 \times 10^{-5}, 1.32 \times 10^{-4}\right.$ and $\left.0.60 \times 10^{-6}\right)$, respectively which are less than 1 indicating no risk [16]. Similar results were observed for adults, except for $\mathrm{Ni}\left(2.10 \times 10^{-6}\right)$ 
Table 3. Heavy Metals Concentration in Tin Mine Tailings and Control Samples in Zabot, and Tafan in Barkin Ladi Local Government Area of Plateau State, Nigeria in $(\mathrm{mg} / \mathrm{kg})$

\begin{tabular}{cccccc}
\hline \hline Heavy metal & & Tin mine Tailing & & Control & USEPA (2009) \\
\hline \hline & S3 & S4 & S3 & S4 & \\
$\mathrm{Pb}$ & 300 & 1,900 & 280 & 270 & 80 \\
$\mathrm{Cr}$ & 900 & 1,000 & 170 & 1,600 & 100,000 \\
$\mathrm{As}$ & 40 & 60 & 70 & 60 & 0.07 \\
$\mathrm{Zn}$ & $\mathrm{ND}$ & 200 & $\mathrm{BDL}$ & 180 & 23,000 \\
$\mathrm{Cd}$ & $\mathrm{ND}$ & $\mathrm{ND}$ & $\mathrm{BDL}$ & $\mathrm{BDL}$ & 1.7 \\
$\mathrm{Ni}$ & $\mathrm{ND}$ & 50 & 70 & 79 & 1,600 \\
$\mathrm{Cu}$ & $\mathrm{ND}$ & $\mathrm{ND}$ & $\mathrm{BDL}$ & $\mathrm{BDL}$ & 3,000 \\
\hline
\end{tabular}

BDL: Below detection limits

Table 4. Human Health Risk Assessment of Non-Carcinogenic Hazard of Heavy Metals for Zabot (S3)

\begin{tabular}{|c|c|c|c|c|c|c|}
\hline \multicolumn{7}{|c|}{ Non Carcinogenic hazards S3 } \\
\hline \multirow{13}{*}{$\begin{array}{l}\text { Tin mine tailing from } \\
\text { mine site }\end{array}$} & Group & Heavy Metal & HQing & HQinh & HQdern-s & $\mathrm{HI}$ \\
\hline & Children & As & $2.65 \times 10^{6}$ & $\mathrm{NC}$ & $2.19 \times 10^{5}$ & $2.87 \times 10^{6}$ \\
\hline & & $\mathrm{Cr}$ & $9.43 \times 10^{6}$ & $8.78 \times 10^{-5}$ & $4.84 \times 10^{5}$ & $9.91 \times 10^{6}$ \\
\hline & & $\mathrm{Pb}$ & $1.9 \times 10^{7}$ & $1.67 \times 10^{-4}$ & $5.83 \times 10^{5}$ & $1.95 \times 10^{7}$ \\
\hline & & $\mathrm{Ni}$ & $3.43 \times 10^{4}$ & $0.74 \times 10^{-6}$ & $0.15 \times 10^{3}$ & $3.46 \times 10^{4}$ \\
\hline & & $\mathrm{Zn}$ & $7.73 \times 10^{4}$ & $2.33 \times 10^{-7}$ & 4.43 & $7.73 \times 10^{3}$ \\
\hline & & Sum & $3.12 \times 10^{7}$ & $2.56 \times 10^{-4}$ & $1.29 \times 10^{6}$ & $3.23 \times 10^{7}$ \\
\hline & Adult & As & $4.03 \times 10^{5}$ & $\mathrm{NC}$ & $4.46 \times 10^{4}$ & $4.48 \times 10^{5}$ \\
\hline & & $\mathrm{Cr}$ & $1.69 \times 10^{-1}$ & $4.44 \times 10^{-3}$ & $1.21 \times 10^{2}$ & $1.27 \times 10^{2}$ \\
\hline & & $\mathrm{Pb}$ & $2.91 \times 10^{6}$ & $0.86 \times 10^{-4}$ & $1.17 \times 10^{5}$ & $3.02 \times 10^{6}$ \\
\hline & & $\mathrm{Ni}$ & $0.53 \times 10^{4}$ & $3.85 \times 10^{-7}$ & $0.03 \times 10^{3}$ & $5.33 \times 10^{3}$ \\
\hline & & $\mathrm{Zn}$ & $1.18 \times 10^{3}$ & $1.06 \times 10^{-7}$ & 8.87 & $1.19 \times 10^{3}$ \\
\hline & & Sum & $3.35 \times 10^{6}$ & $4.53 \times 10^{-3}$ & $1.62 \times 10^{5}$ & $3.48 \times 10^{6}$ \\
\hline
\end{tabular}

Soil from agricultural farmland around mine site

\begin{tabular}{llllll} 
Children & $\mathrm{As}$ & $2.03 \times 10^{6}$ & $\mathrm{NC}$ & $1.79 \times 10^{5}$ & $2.21 \times 10^{6}$ \\
& $\mathrm{Cr}$ & $7.86 \times 10^{6}$ & $7.05 \times 10^{-5}$ & $4.02 \times 10^{4}$ & $7.72 \times 10^{6}$ \\
& $\mathrm{~Pb}$ & $1.50 \times 10^{7}$ & $1.32 \times 10^{-4}$ & $4.60 \times 10^{5}$ & $1.54 \times 10^{7}$ \\
& $\mathrm{Ni}$ & $2.76 \times 10^{4}$ & $0.60 \times 10^{-6}$ & $0.12 \times 10^{3}$ & $2.77 \times 10^{4}$ \\
& $\mathrm{Zn}$ & $7.33 \times 10^{3}$ & $1.96 \times 10^{6}$ & $4.22 \times 10^{1}$ & $7.37 \times 10^{3}$ \\
& $\mathrm{Sum}$ & $2.49 \times 10^{7}$ & $1.96 \times 10^{6}$ & $6.79 \times 10^{5}$ & $2.54 \times 10^{7}$ \\
\multirow{4}{*}{ Adult } & & & & \\
& $\mathrm{As}$ & $3.37 \times 10^{5}$ & $\mathrm{NC}$ & $3.71 \times 10^{4}$ & $3.71 \times 10^{4}$ \\
& $\mathrm{Cr}$ & $0.68 \times 10^{3}$ & $5.56 \times 10^{3}$ & $0.51 \times 10^{5}$ & $5.72 \times 10^{4}$ \\
& $\mathrm{~Pb}$ & $2.29 \times 10^{6}$ & $0.66 \times 10^{4}$ & $0.92 \times 10^{5}$ & $2.88 \times 10^{6}$ \\
& $\mathrm{Ni}$ & $4.22 \times 10^{3}$ & $2.10 \times 10^{-6}$ & $0.02 \times 10^{3}$ & $4.24 \times 10^{3}$ \\
& $\mathrm{Zn}$ & $1.12 \times 10^{4}$ & $1.43 \times 10^{-7}$ & $8.43 \times 10^{-3}$ & $1.12 \times 10^{4}$ \\
& $\mathrm{Sum}$ & $2.64 \times 10^{6}$ & $1.22 \times 10^{4}$ & $1.80 \times 10^{5}$ & $2.99 \times 10^{6}$
\end{tabular}


Table 5. Human Risk Assessment of Non-carcinogenic Hazard of Heavy Metals in Tafan (S4)

Tin mine tailing from mine site

Soil from agricultural farmland around mine site

\section{Non Carcinogenic hazards S4}

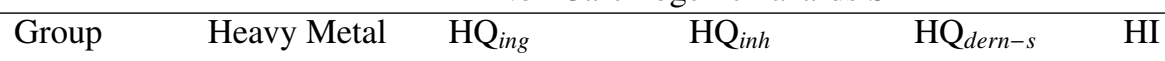

Children As

Adult

Children

NC: Not Calculated

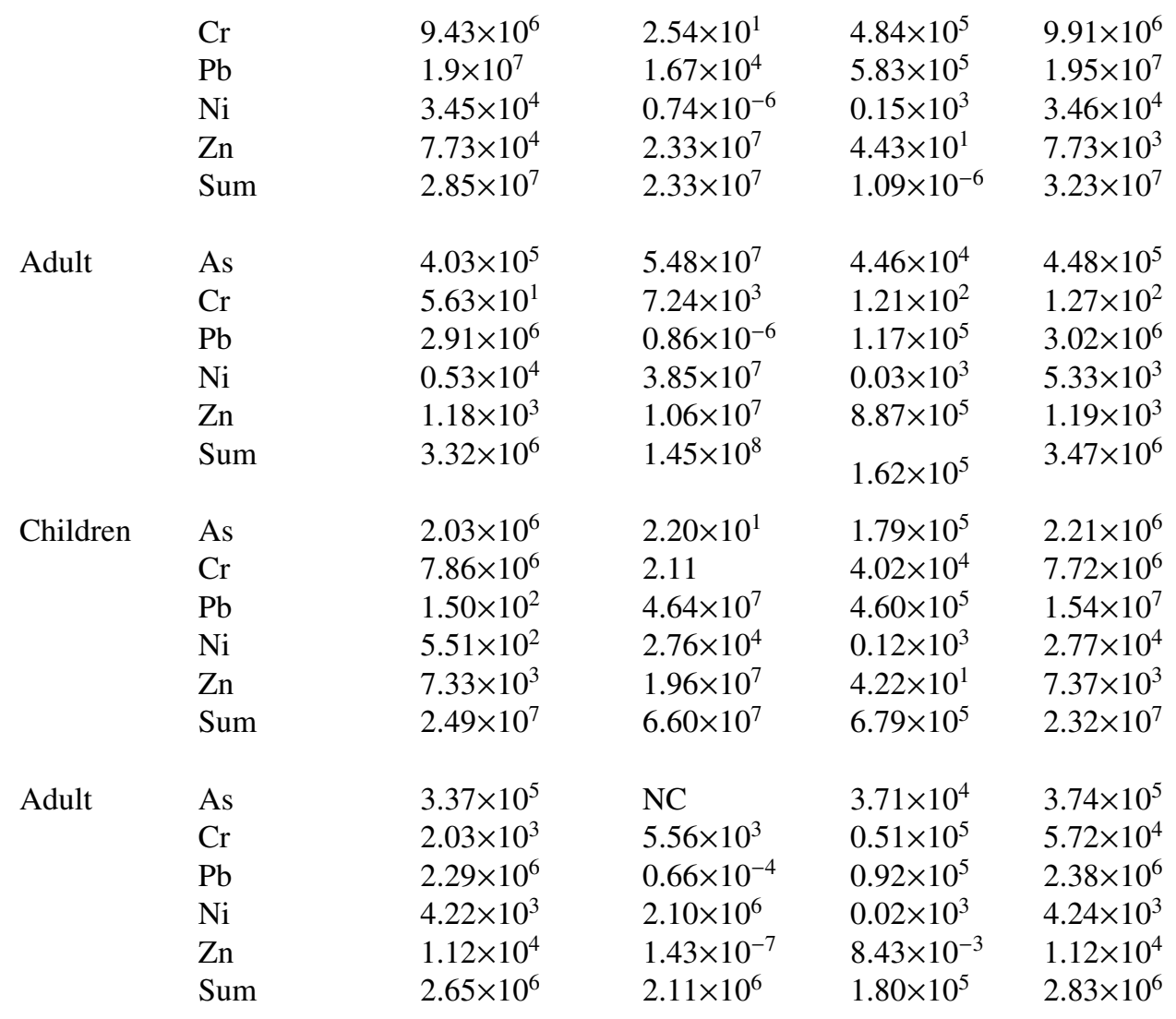

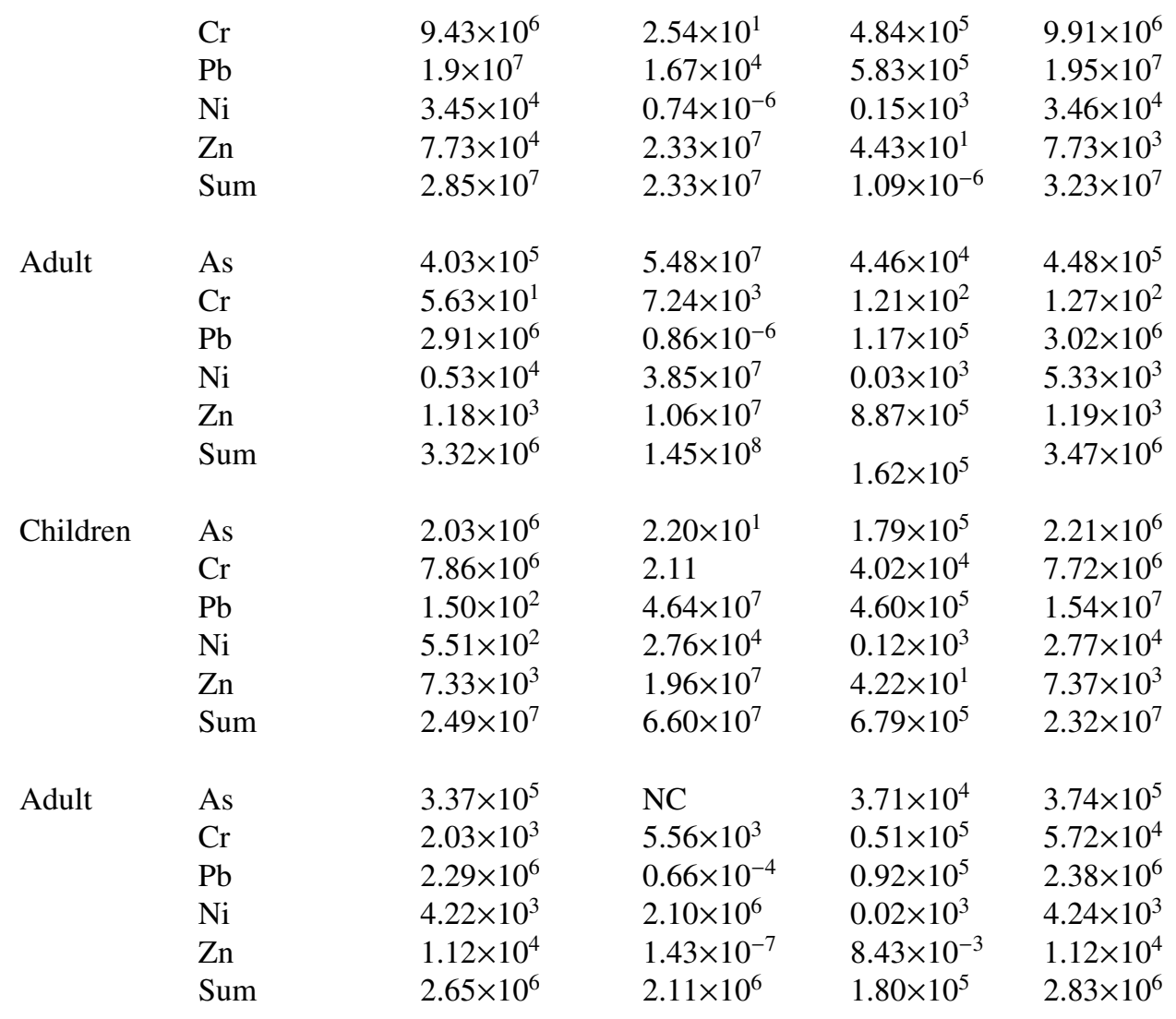

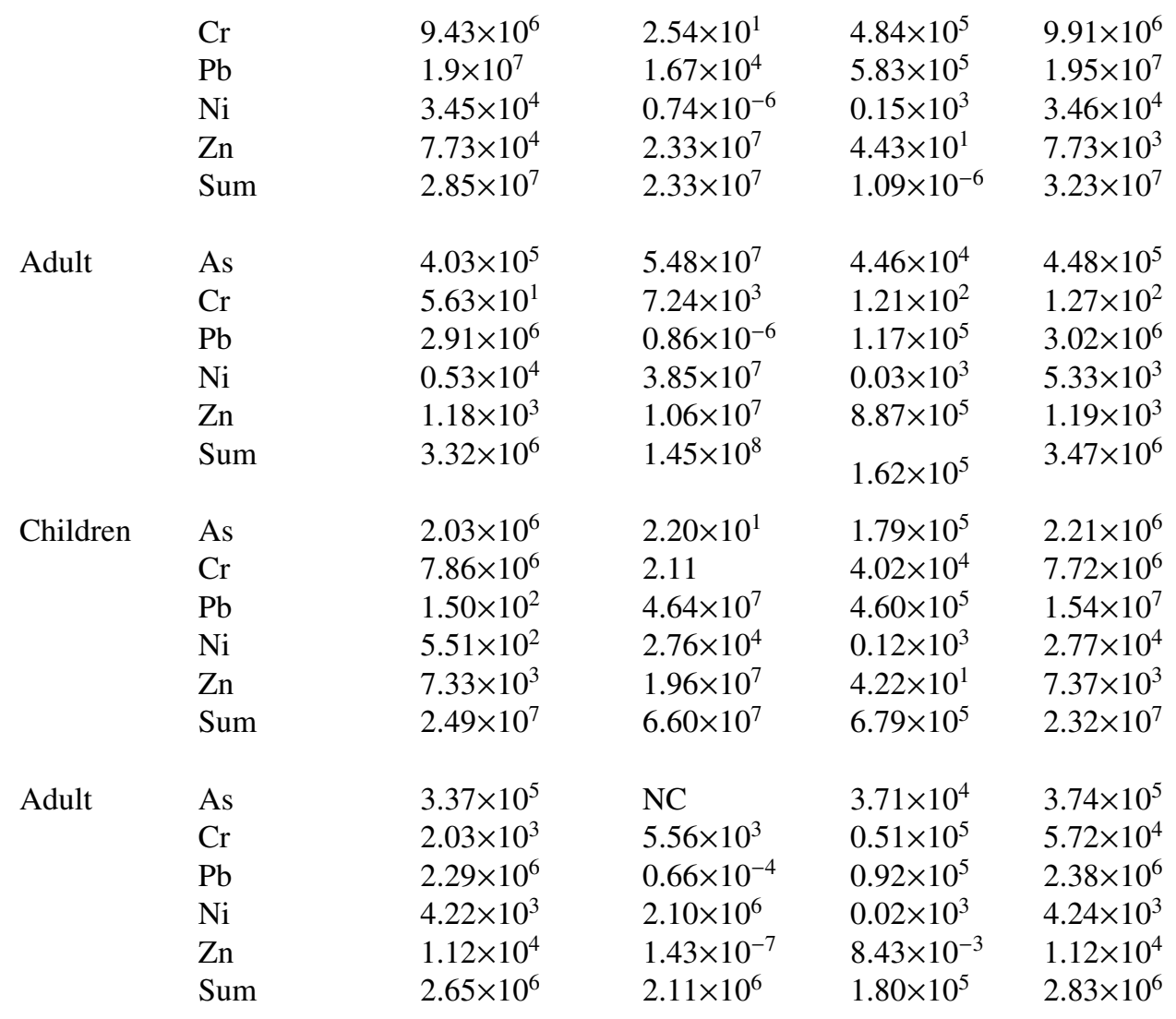

Table 6. Individual Carcinogenic Risk at the site Zabot (S3)

\begin{tabular}{|c|c|c|c|c|c|}
\hline \multirow[t]{2}{*}{ Group } & \multirow[t]{2}{*}{ "Heavy Metal } & \multicolumn{3}{|c|}{ Carcinogenic Risk S3 } & \multirow[t]{2}{*}{ 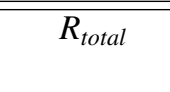 } \\
\hline & & $\mathbf{R}_{\text {ing-s }}$ & $\mathrm{R}_{i n h-s}$ & $\mathbf{R}_{d e r n-s}$ & \\
\hline \multirow{5}{*}{ Tin mine tailings from mine site } & 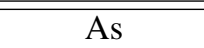 & $1.17 \times 10^{2}$ & $1.14 \times 10^{-8}$ & 22.18 & $1.39 \times 10^{2}$ \\
\hline & $\mathrm{Cr}$ & $\mathrm{NC}$ & $1.64 \times 10^{-7}$ & $\mathrm{NC}$ & $2.02 \times 10^{-7}$ \\
\hline & $\mathrm{Pb}$ & $3.30 \times 10^{3}$ & $\mathrm{NC}$ & $\mathrm{NC}$ & $3.30 \times 10^{3}$ \\
\hline & $\mathrm{Ni}$ & $\mathrm{NC}$ & $8.17 \times 10^{-8}$ & $\mathrm{NC}$ & $8.17 \times 10^{-8}$ \\
\hline & Sum & $3.41 \times 10^{3}$ & $2.57 \times 10^{-3}$ & 22.18 & $16.41 \times 10^{6}$ \\
\hline \multirow{5}{*}{ Soil from agricultural farmland around mine site } & As & $7.61 \times 10^{2}$ & $2.12 \times 10-8$ & $1.60 \times 10^{1}$ & $3.42 \times 10^{3}$ \\
\hline & $\mathrm{Cr}$ & $\mathrm{NC}$ & $2.64 \times 10^{-5}$ & $\mathrm{NC}$ & $2.64 \times 10^{-5}$ \\
\hline & $\mathrm{Pb}$ & $2.16 \times 10^{1}$ & $\mathrm{NC}$ & $1.67 \times 10^{1}$ & $38.30 \times 10^{1}$ \\
\hline & $\mathrm{Ni}$ & $\mathrm{NC}$ & $6.90 \times 10^{-8}$ & $\mathrm{NC}$ & $6.90 \times 10^{-8}$ \\
\hline & Sum & $78.26 \times 10^{2}$ & $2.64 \times 10^{-5}$ & $32.70 \times 10^{1}$ & $3.80 \times 10^{9}$ \\
\hline
\end{tabular}


Table 7. Individual Carcinogenic Risk at the site Zabot (S3)

\begin{tabular}{ccccccc}
\hline \hline Group & Heavy Metal & \multicolumn{3}{c}{ Carcinogenic Risk S3 } & \multicolumn{2}{c}{$R_{\text {total }}$} \\
& & $\mathrm{R}_{\text {ing-s }}$ & $\mathrm{R}_{\text {inh }-s}$ & $\mathrm{R}_{\text {dern }- \text { s }}$ & \\
\hline \hline & $\mathrm{As}$ & $4.55 \times 10^{2}$ & $4.16 \times 10^{-8}$ & 115.14 & $5.70 \times 10^{2}$ \\
& $\mathrm{Cr}$ & $\mathrm{NC}$ & $1.82 \times 10^{-7}$ & $\mathrm{NC}$ & $1.82 \times 10^{-7}$ \\
Tin mine tailings from mine site & $\mathrm{Pb}$ & $3.63 \times 10^{4}$ & $\mathrm{NC}$ & $\mathrm{NC}$ & $3.63 \times 10^{4}$ \\
& $\mathrm{Ni}$ & $\mathrm{NC}$ & $9.64 \times 10^{-9}$ & $\mathrm{NC}$ & $9.64 \times 10^{-9}$ \\
& $\mathrm{Sum}$ & $36.76 \times 10^{3}$ & $2.33 \times 10^{-4}$ & 115.14 & $9.64 \times 10^{9}$ \\
\hline & & & & & \\
& $\mathrm{As}$ & $1.14 \times 10^{3}$ & $3.46 \times 10^{-8}$ & $2.4 \times 10^{1}$ & $1.16 \times 10^{3}$ \\
Soil from agricultural farmland around mine site & $\mathrm{Cr}$ & $1.71 \times 10^{-7}$ & $\mathrm{NC}$ & $\mathrm{NC}$ & $1.71 \times 10^{-7}$ \\
& $\mathrm{~Pb}$ & $2.05 \times 10^{2}$ & $\mathrm{NC}$ & 106.11 & $31.1 \times 10^{2}$ \\
& $\mathrm{Ni}$ & $\mathrm{NC}$ & $1.51 \times 10^{-8}$ & $\mathrm{NC}$ & $1.51 \times 10-8$ \\
& $\mathrm{Sum}$ & $1.34 \times 10^{3}$ & $4.97 \times 10^{-2}$ & $130.11 \times 10^{2}$ & $4.27 \times 10^{3}$ \\
\hline NC: Not Calculated & & & & &
\end{tabular}

and $\mathrm{Zn}\left(1.43 \times 10^{-7}\right)$ that are less than 1 and pose no risk [16]. Also, the $\mathrm{HI}$ values were all greater than 1 , indicating significant effects. The summation of $\mathrm{HQ}$ for ingestion in the mining and control sites are $\left(3.12 \times 10^{7}\right.$ and $\left.3.35 \times 10^{6}\right)$, and $\left(2.49 \times 10^{7}\right.$ and $2.64 \times 10^{6}$ ) for children and adults respectively. From the results, it is observed that the mining site poses higher risk than the control site, and the children are at higher risk than the adults due to their high values [27]. Similar results were reported by Ngole-Jeme and Fantke [28] for, studies on ecological and human health risks associated with abandoned gold mine tailings contaminated soil.

The non-carcinogenic risk (NCR) results for Tafan (S4) are presented in Table 5. For mining site, the HQ values for children were found to be greater than 1, except for As and Ni with values $\left(1.80 \times 10^{-8}\right.$ and $\left.0.74 \times 10^{-6}\right)$ via ingestion and inhalation respectively. According to Man et al., [15], HQ greater than 1 is an indication of high risk exposure. For the adults, the HQ were found to be greater than 1 , except for $\mathrm{Pb}$ with value $0.86 \times 10^{-6}$ which is less than 1 indicating significant and no significant effect respectively [28].

For the control site (S4) results for children (Table 5), it was observed that both the HQ and HI values were all greater than 1 representing significant effects [16]. The adults result for As, $\mathrm{Cr}, \mathrm{Pb}, \mathrm{Ni}$ and $\mathrm{Zn}$ also showed that $\mathrm{HQ}$ and $\mathrm{HI}$ values were all greater than 1 , except for $\mathrm{Zn}$ which has values of $1.43 \times 10^{-7}$ and $8.43 \times 10^{-3}$ for inhalation and dermal less than 1 , indicating cancer and non-cancer risk respectively [15]. The summation of $\mathrm{HQ}$ for ingestion in the mining and control sites are $\left(2.85 \times 10^{7}\right.$ and $\left.3.32 \times 10^{6}\right)$, and $\left(2.49 \times 10^{7}\right.$ and $\left.2.65 \times 10^{6}\right)$ for children and adults respectively. In terms of population group for NCRs, it is observed that the mining site pose more risk than the control site, and the children are at higher risk than the adults due to their high values [28]. From the results for the three different exposure pathways of metals for children and adults, the contribution of HQ is in the order of ingestion greater than dermal and dermal greater than inhalation for $\mathrm{As}, \mathrm{Cr}, \mathrm{Pb}, \mathrm{Ni}$ and $\mathrm{Zn}$ in the studied mining and control areas for S4.

\subsubsection{Carcinogenic Risk Assessment for $\mathrm{S} 3$ and $\mathrm{S} 4$}

The Carcinogenic risks associated with $\mathrm{As}, \mathrm{Cr}, \mathrm{Pb}$ and $\mathrm{Ni}$ were evaluated as presented in Table 6 . From the S3 results, the $\mathrm{R}_{\text {total }}$ for mining site were found to be $\left(1.39 \times 10^{2}, 2.02 \times 10^{-7}\right.$, $3.30 \times 10^{3}$ and $\left.8.17 \times 10^{-8}\right)$, and control site $\left(3.42 \times 10^{3}, 2.64 \times\right.$ $10^{-5}, 38.30 \times 10^{1}, 6.90 \times 10^{-8}$ ) for $\mathrm{As}, \mathrm{Cr}, \mathrm{Pb}$ and $\mathrm{Ni}$ respectively. For carcinogenic risk (Table 6$)$, total cancer risk $\left(R_{\text {total }}\right)$ values greater than $1 \times 10^{-4}$ represents elevated risks, $\mathrm{R}_{\text {total }}$ less than $1 \times 10^{-6}$ represents no significant health risk, and $\mathrm{R}_{\text {total }}$ values between $1 \times 10^{-4}$ and $1 \times 10^{-3}$ are generally considered acceptable [26, 17]. From the mining and control results, it was observed that the values of the $\mathrm{R}_{\text {total }}$ for $\mathrm{As}$ and $\mathrm{Pb}$ were more than the acceptable threshold, while $\mathrm{Cr}$ and $\mathrm{Ni}$ were below the threshold representing elevated risks and no significant health risk respectively [17]. Similar results were observed by Narsimha and Haike [26] for, studies on distribution, contamination, and health risk assessment of heavy metals in surface soils from northern Telangana, India.

From results of the mining site $\mathrm{S} 4$ (Table 7), the $\mathrm{R}_{\text {total }}$ were found to be $\left(5.70 \times 10^{2}, 1.82 \times 10^{-7}, 3.63 \times 10^{4}\right.$ and $\left.9.64 \times 10^{-9}\right)$, and the control were found to be $\left(1.16 \times 10^{3}, 1.7110^{-7}, 31.1 \times\right.$ $10^{2}$ and $1.51 \times 10^{-8}$ ) for $\mathrm{As}, \mathrm{Cr}, \mathrm{Pb}$ and $\mathrm{Ni}$, respectively. From the results of the mining and control sites, it is observed that the values for $\mathrm{As}$ and $\mathrm{Pb} \mathrm{R}_{\text {total }}$ were higher than the acceptable threshold, while $\mathrm{Cr}$ and $\mathrm{Ni}$ were below the threshold. These results showed that $\mathrm{As}$ and $\mathrm{Pb}$ pose elevated risks, while $\mathrm{Cr}$ and $\mathrm{Ni}$ does not pose any significant health risk [26, 17]. Furthermore, values from the mining site indicate more pollution than the control.

\section{Conclusion}

The results of the analysis of this research work showed that both the mining and control sites in Zabot and Tafan in Barkin Ladi L.G.A and environs contains certain concentration of heavy metals $(\mathrm{Pb}, \mathrm{Ni}, \mathrm{Zn}, \mathrm{Cr}, \mathrm{Cd}$, As and $\mathrm{Cu})$ in different fractions. The surface morphology of the tin mine tailings through the use of scanning electron microscopy (SEM) 
technique revealed homogenous sized particles with fine porous structure, and rough area having different irregular shapes of varying sizes and pores distributed over the surface for both $\mathrm{S} 3$ and S4 respectively. From the hazard quotient (HQ) and human health risk derived from carcinogenic and non-carcinogenic hazards for adults and children, it is observed that the mining site pose more risk than the control site, and children are at higher risk than the adults due to their high values. From the results for the three different exposure pathways of metals for children and adults, the contributions of HQ are in the order of ingestion $>$ dermal $>$ inhalation for $\mathrm{As}, \mathrm{Cr}, \mathrm{Pb}, \mathrm{Ni}$ and $\mathrm{Zn}$ in the studied mining and control areas for S4.

\section{Acknowledgements}

We wish to thank those who work on the abandoned open tin mine tailings site for giving us permission to collect samples for this research. We wish to acknowledge the effort of Godwin Mafuyai and Kelvin Guyit of the department of Natural Sciences, University of Jos, Nigeria for their technical assistance in the course of this research work.

\section{References}

[1] V. Aigbodion, A. Abdulrasheed, S. Olajide, J. Agunsoye \& I. Suleiman, "Potential of Tin Tailings an Industrial Waste for Refractory Materials", Journal of Minerals and Materials Characterization and Engineering 9 (2010) 2 .

[2] A. O. Dada, F. A. Adekola \& E. O. Odebunmi, "Kinetics, mechanism, isotherm and thermodynamic studies of liquid-phase adsorption of $\mathrm{Pb} 2+$ onto wood activated carbon supported zerovalent iron (WAC-ZVI) nanocomposite", Cogent Chemistry 3 (2017) 1351653

[3] D. D. Bwede, R. A. Wuana, M.E. Khan, G. O. Egah, A. U. Itodo \& E. B. Duwong, "Physicochemical Characterization and Assessment of Ecological Risk of Heavy Metals in Tin Mine Tailings in Riyom Local Government Area of Plateau State, Nigeria, Journal of Environmental Analytical Chemistry 6 (2019) 3.

[4] E. I. B. Chopin \& B. J. Alloway, "Distribution and Mobility of Trace Elements in soils and vegetation around the mining and smelting areas of Tharsis, Riotinto and Huelva, Ibrerian Pyrite Belt, SW Spain", Air and Soil Pollution 182 (2007) 1

[5] I. G. E. Ibeanu, "Tin mining and ore processing in Nigeria: cause for concern", Journal of Environmental. Radioactivity 64 (2003).

[6] G. O. Egah, B. N. Hikon, G. S. Ngantem, E. A. Yerima, M. Omovo, E. Ogah, F. A. Aminu, "Synergistic Study of Hydroxyiron (III) and Kaolinite Composite for the Adsorptive Removal of Phenol and Cadmium', International Journal of Environmental Chemistry 3 (2019) 1. doi: 10.11648/j.ijec.20190301.15.

[7] B. Chen, H. Qiu, Y. Guo, L. Wang \& X. Wang, "Heavy metal contamination and health risk assessment in the zinc mine set area of Youxi, China", Journal of Xiamen University (Natural Science) 51 (2012) 2.

[8] A. O. Dada, F. A. Adekola \& E. O. Odebunmi, "Kinetics and Equilibrium Models for Sorption of Cu(II) onto a Novel Manganese Nano-Adsorbent", Journal of Dispersion Science and Technology 37 (2015) 1

[9] J. A. R. Martín, C. Gutiérrez, M. Escuer, M. T. García-González, R. Campos-Herrera \& N Águila, "Effect of mine tailing on the spatial variability of soil nematodes from lead pollution in La Union (Spain)", Science of the Total Environment 473 (2014) 474.
[10] G. M. Mudd, "An analysis of historic production trends in Australian base metal mining", Ore Geology Reviews 32 (2007) 1.

[11] B. Wei, F. Jiang, X. Li, and S. Mu, "Heavy metal induced ecological risk in the city of Urumqi, NW China", Environment Monitoring Assessment 160 (2010) 33.

[12] Z. Li, Z. Ma, T. J. Vander Kuijp, Z. Yuan \& L. A Huang, "Review of Soil Heavy Metal Pollution from Mines in China: Pollution and Health Risk Assessment", Science of the Total Environment 468 (2013) 469.

[13] X. Qing, Z. Yutong \& L. Shenggao, "Assessment of Heavy Metal Pollution and Human Health Risk in Urban Soils of Steel Industrial City (Anshan), Liaoning, Northeast China, Ecotoxicology and Environmental Safety 120 (2015) 377.

[14] USEPA, "Example Exposure Scenarios National Center for Environmental Assessment", Washington, DC. EPA/600/R-03/036.National Information Service Springfield, VA; PB2003-103280 (2003).

[15] Y. B Man, X. L. Sun \& Y. G. Zhao, "Health risk assessment of abandoned agricultural soils based on heavy metal contents in Hong Kong, the world's most populated city." Environment International 36 (2010) 6.

[16] Y. Huang, Y. Xia-Li, J. Yang, M. Xu, B. Sun, F. Gao \& N. Wang, "Harmful Chemicals in Soil and Risk Assessment of an Abandoned Open Dumpsite in Eastern China", Journal of Chemistry Article, 10 (2014) 297686.

[17] M. Fryer, C. D Collins, H. Ferrier, R. N Colvile \& M. J. Nieuwenhuijsen "Human exposure modelling for chemical risk assessment: a review of current approaches and research and policy implications", Environmental Science and Policy 9 (2006) 3.

[18] Y. Li, H. Yetang, W. Duojun \& Z. Yonhzuan, Determination of free heavy metal ion concentrations in soils around Cadmium rich Zinc deposit. Geochemical Journal 13 (2007) 235.

[19] B. N Hikon, G. S Ngantem, G. O. Egah \& D. D Bwede Assessment of heavy metals contamination in soils impacted by mining activities in akwana, taraba state, Nigeria - Research journal of Life Sciences Bioinformatics pharmaceutical and chemical sciences 4 (2018) 5.

[20] E. Berrezueta \& R. Castroviejo, "Automated microscopic characterization of metallic ores with image analysis", Review Metal Journal 43 (2007) 294.

[21] A. Ayeshamarian, C. Sanjeeviraja \& R. S. Perumal, "Synthesis, Structural and optical characterizations of SNO2 Nanoparticles", Journal on Photonics and Spintronics 2 (2013) 2324.

[22] E. Ogah, G. O. Egah, P. A. Neji, F. T. Samoh, J. D. Dodo, C. O. Anidobu, S. K Amee \& D. D. Bwede, "Analysis of heavy metal concentration in auto-mechanic dumpsites in Makurdi Metropolis, North Central Nigeria", Journal of Environmental Chemistry and Ecotoxicology 12 (2020) 1. DOI: $10.5897 / J E C E 2020.0463$.

[23] E. I. Uwah, N. P. Ndahi \& V. O. Ogugbuaja, "Study of the levels of some agricultural pollutants in soils and waterleaf (Talinum triangulare) obtained in Maiduguri, Nigeria', Journal of Applied Science in Environmental Sanitation 4 (2009) 2.

[24] Z. Monika \& M. Romic Soil contamination by trace metals. Geochemical behavior as an element of Risk assessment, Journal of Earth and Environmental Science 3 (2011) 34.

[25] A. D. K Banerjee, "Heavy metal levels and solid phase speciation in street dusts of Delhi, India", Journal of Environmental Pollution 123 (2003) 1.

[26] N. Adimalla \& H. Wang, "Distribution, contamination, and health risk assessment of heavy metals in surface soils from northern Telangana, India", Arabian Journal of Geosciences 11 (2018) 684.

[27] C. S. Qu, Z. W. Ma, J. Yang, Y. Liu, J. Bi \& L. Huang, "Human Exposure Pathways of Heavy Metals in a Lead-Zinc Mining Area, Jiangsu Province", China. Plos One 7 (2012) 11

[28] V. M Ngole-Jeme \& P. Fantke, "Ecological and human health risk associated with abounded gold mining contaminated soil", Review Metal Journal 42 (2017) 100. 